

\section{Factors Affecting the Adoption of Mobile Payment Systems: An Empirical Analysis}

\section{İkram Daştan Cem Gürler}

\section{Introduction}

Mobile technologies have not only become widespread rapidly, but they currently also have the advantage of reaching the customers for firms. Mobile technologies have lots of advantages against other technologies, such as interacting with anybody in anywhere, being in use individualistically, customized information and services, and getting quick answers from users. According to The World Factbook, $87 \%$ of the world's population (6.8 billion people) were using mobile phones in 2013. Moreover, mobile internet usage has been widespread day by day. In pursuant of a report published by Statcounter (a web traffic analysis tool), the share of mobile devices (phones and tablets) internet usage was 35.3\% in 2014 (Statcounter, 2014). When taking the statistics of mobile usage into consideration, using mobile devices as a transactional device should not be a surprise (van der Heijden, 2002). The use of mobile devices in payments can be regarded as a venture for investors and service providers. The enterprises, who noticed the venture, have continued investing in order to benefit from this situation. Samsung generated its own mobile payment system (MPS), Samsung Pay, and other market players have also tried to have a position in market. PayPal (an online payment system) has bought Paydiant in order to keep up with the competition. Apple announced Apple Pay in the 2014 Apple's launch event, Google purchased Softcard in 2014, and Android Pay was announced by Google in 2015 spring. These can be shown as evidences to those investments. On the basis of making such investments, Google and Apple expect consumers to shift their preferences from traditional payment systems to MPS.

When we compare MPS against other payment systems, the most important feature of MPS is that it brings mobility. Individuals can make their payments independent of time and place. While the smartphone usage has been continuing to rise, MPS will take over the traditional payments system and also will be future of payment systems. Despite its age, MPS is boosting its popularity each day. With reference to PayPal research in 22 countries, 33\% of online shopping has been carried out by smartphones. Considering the history of smartphones, the $33 \%$ share shows the importance of
MPS and smartphones. Ipsos ING's research in 15 countries has shown that the $56 \%$ of participants from Turkey has made online payments via mobile application at least once (ING, 2015). However, this percentage is just 33\% in Europe. The percentage of young people in Turkey is higher than Europe. The difference between these numbers could be derived from Turkey's youth bulge. This is probably because generation Y can better keep up with new technologies comparison to generation $\mathrm{X}$.

Mobility can be shown as an important factor affecting MPS, but it is hard to state mobility as the only factor. For instance, the perceived trust factor is as important as mobility. Trust in MPS occurs differently than the physical payment. Because, the consumer doesn't contact with another person and the transactions are in progress between consumer and mobile devices. Reasons, such as the uncertainty about how the transactions occur on background and ill-wishers, influence consumer trust in MPS. However security certificates, mobile wallets and such factors can settle up issue of trust.

MPS may be evaluated as a future payment system. This paper aims to investigate the factors that affect the Adoption of MPS conceptually and empirically. In this context, in following section we examine the MPS literature and its conceptual framework. The last section presents findings and discusses limitations as well as directions for future research.

\section{Literature and Theoretical Framework}

This study used the technology acceptance model (TAM) to explain the factors affecting the Adoption of MPS. The TAM was introduced by Davis (1989) to explain and estimate the behavior of technology users (Davis, 1989). Nowadays, TAM is widely used for foreseeing the individuals' adoption of information technologies and intention to use. According to this model, perceived ease of use and perceived usefulness influence behavior developed by the user towards information systems. This behavior channels the individual's intention and leads to acceptance (Özer et al., 2010). The TAM has become the most popular model to predict both as the use information technology and intention to use (Lu et al., 2003).

Mobile technologies on the one hand make life easier progressively and have numerous advantages for the companies to reach customers (IAB, 2010). Features such as individual use, personalized information and services as well as feedbacks from users make mobile technologies superior (Barnes, 2002; Kannan et al., 2001). 
Mobile technologies progress as a payment system. In recent years, there has been an increasing amount of literature on MPS. MPS can be defined as a payment system in which mobile devices are used to initiate, activate, and/or confirm any payment (Karnouskos and Fokus, 2004). In short, MPS is a payment that is conducted with a mobile device, such as smartphones and tablets. Combining these two definitions, MPS is like a kind of electronic payment system, but when we compare MPS with electronic payment systems, it has more mobility. There is a large volume of publications that describe the factors affecting adoption of MPS; perceived ease of use, perceived usefulness, perceived cost (van der Heijden, 2002), mobility, perceived trust, perceived expressiveness (Zmijewska et al., 2004), relative advantages, compatibility, complexity, network externalities and costs (Mallat, 2007). Schierz et al. carried out a survey among 1447 individuals to investigate the factors affecting Adoption of MPS (Schierz et al., 2010). Results showed that, in comparison with other factors, perceived compatibility has more and more significant effect on Adoption of MPS. In Korea, a research studied how the factors (innovativeness, m-payment knowledge, mobility, reachability, compatibility, convenience, perceived usefulness and perceived ease of use) affect the adoption of MPS, and it has reported that the most important indicators of adoption of MPS are perceived usefulness and perceived ease of use (Kim et al., 2010). Yang et al. found that behavioural beliefs, social influence and personal traits have direct and significant influence on the adoption of MPS (Yang et al., 2012). Zhou (2013) showed that flow is the most important factor affecting continuance to use MPS (Zhou, 2013). In the same study, it is emphasized that quality of service is the most significant indicator of flow and trust. Srivastava et al. demonstrated that, perceived reputation is the best predictor of trust and there is a negative correlation between perceived reputation and environmental risk (Srivastava et al. 2010).

Because of the law numbered 6493 that is in effect at Turkey, e-commerce companies and companies using virtual point of sale (POS) are not allowed to save and store the customer payment data, such as credit card number and personal data. The purpose of this law is to secure sensitive data and close some gaps about MPS. In mobile systems, trust is one of the most important factors affecting adoption (Mallat, 2007; Chandra et al., 2010; Zhou, 2013). Perceived reputation and environmental risk are discussed as the indicators of perceived trust in this research. Throughout this study, the term perceived reputation will refer to the evaluation of firm based on its performance. A number of studies have tested perceived reputation as an element of perceived trust (Jin et al., 2007; Moi and Mohtashemi, 2002). In this paper, perceived reputation has been added to the research model as an indicator of perceived trust.

$H_{1}$ : Perceived reputation positively affects perceived trust.

Privacy and security concerns on online payment systems influence customer views. Customers don't have transaction processes in hand in online payment systems and this stimulates the uncertainty and causes mistrust. Pavlou (2003) has stated that lack of authority on transactions would increase the risk perception of customers and influence trust negatively (Pavlou, 2003). Also, threat of hackers and possibility of customer information theft give rise to increased environmental risk. By taking such cases into consideration, it is hypothesized that;

\section{$\mathrm{H}_{2}$ Environmental risk negatively influences perceived trust.}

Besides outdated technologies, mobility has revealed more substantial and complicated problems (Karnouskos et al., 2004). Griffin has defined trust as the belief that a feature of an object, an event occur or a person's behavior when faced with a risky situation, to achieve an intended purpose (Demircan and Ceylan, 2003). In the e-payment systems (also MPS), context of perceived trust is consumers' belief that e-payment transactions will be processed in accordance with their expectations (Kim et al., 2010; Mallat, 2007). Due to MPS containing environmental and operational uncertainty, customers may lack trust. These can negatively influence both the adoption of MPS and intention to use MPS. However, trust in vendors and service providers reduce risks of MPS (Mallat, 2007).

$H_{3:}$ Perceived trust negatively influences adoption of MPS.

Davis (1989) defined perceived usefulness as a belief that, using a particular system would enhance job performance (Davis, 1989). It can also be expressed as a belief about using a familiar product which is known before cash is used (Tzou and Lu, 2009). A considerable amount of literature has been observed to explain the relationship between perceived usefulness and adoption of MPS (Davis, 1989; Adams et al., 1992; Fenech, 1998). Davis (1989) found that perceived usefulness has significant effect on intention to use. MPS should be independent of time and place, so individuals could perceive MPS useful. Thus, $\mathrm{H}_{4}$ is developed accordingly.

$H_{4}$ : Perceived usefulness positively influences adoption of MPS. 
Davis (1989) also explained perceived ease of use as the degree to which a person believes that using a particular system would be effortless. There is a consensus among social scientists that perceived ease of use is an element of adoption of MPS (Davis, 1989; Gefen and Straub, 2000; Venkatesh, 2000). A number of studies showed that, a system which is learned and managed easily satisfies individuals and increases intention to use the system (Childers et al., 2001; Szymanski and Hise, 2000). Also, some studies have confirmed that perceived ease of use has a strong effect on perceived usefulness (Davis, 1989; Gefen et al., 2003; Deveraj et al., 2003). It is anticipated that, when individuals think ease of use of MPS increases, intention to use also increases. From this point forth, $\mathrm{H}_{5}$ is tested to investigate how perceived ease of use affects adoption of MPS,

$H_{5}$ : Perceived ease of use positively influences adoption of MPS.

One of the most important features that distinguish MPS from traditional payment systems is mobility. In the MPS literature, mobility tends to be used to refer to the individuals' ability to make payments independent of time and place. People can't be located more than one place physically with recent conditions. More clearly, people are unable to buy something from the mall or pay the bill when they are at work, at home or when travelling. However, people can make all the transactional processes through MPS. Based on the above discussion, hypothesis is proposed as follows:

\section{$H_{6}$ : Mobility positively influences adoption of MPS.}

Attitude refers to the individuals' tendency and feelings toward an object, an idea or a behavior (Küçük, 2011). Attitude is an indicator of behavior and it is formed just before behavior. Attitude also brings to light the behavior (Kalkan, 2011). For this reason, it can be said that there is a positive relationship between attitudes and intention to use. Actually, studies have confirmed that proposition (Yang ve Yoo, 2004; Kalkan, 2011, Y1lmaz vd, 2009). Davis (1989) has found that attitude has a strong effect in comparison to other factors. In light of these findings and discussion, the $\mathrm{H}_{7}$ hypothesis is developed.

\section{$H_{7}$ : Attitude positively influences intention to use MPS.}

In this context, the proposed model of the present study is shown in Figure 1.

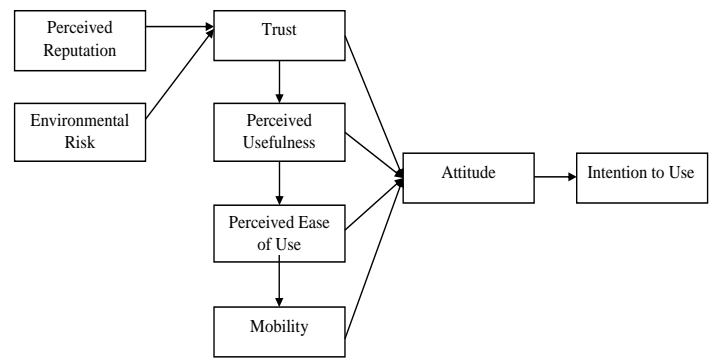

Figure 1. Research Model

\section{Methodology}

\subsection{Research Objective}

The major objective of this study is to determine the direction of the effects of factors listed as perceived trust, perceived usefulness, perceived ease of use and perceived mobility on adoption of MPS.

\subsection{Sampling and Data Collection}

Data to answer the research questions were collected through surveys. The online questionnaire form was available on the relevant webpage almost for two months and every completed questionnaire was evaluated. At the same time, we have also collected data via convenience sampling. With the exclusion of missing and incomplete questionnaires, the research was applied to a total of 225 individuals. The first part of the questionnaire has included demographic factors such as age, gender, income statue and educational background. Of all 225 participants, 125 were male (55.5\%), and 100 were female $(44.4 \%) .1 .33 \%$ of individuals were under $17,52.44 \%$ were between $18-24,38.22 \%$ were between $25-34,6.66 \%$ were $35-44,2.88 \%$ were $45-54$, and $0.44 \%$ were over 55 years old. $\% 42.2 \%$ of individuals had income levels below TL 1000, 23.55\% had income levels between \$501-1000, 17.33\% had income levels between \$1001-1500, 12.88\% had income levels between \$15012000, 2.22\% had income levels between \$2001-2500, and $1.77 \%$ had income levels above $\$ 2500$. $1.33 \%$ of participants were elementary school graduates, $6.25 \%$ were high school graduates, $3.12 \%$ had associate degrees, $71.42 \%$ were college graduates, $14.73 \%$ had post graduate degrees, and $3.12 \%$ were $\mathrm{PhD}$ graduates.

\subsection{Data Analysis}

Prior to applying structural equation modeling, the measurement model was tested with the two-stage approach model of Anderson and Gerbing (1988). Firstly, the confirmatory factor analysis was conducted to 
test the validity and reliability of the measurement model. Then, the research hypotheses were tested for the structural model.

The variables of the proposed model are perceived trust, perceived usefulness, perceived ease of use, and perceived mobility respectively. The measurement model (Figure. 1) was tested by employing the calculation of maximum-likelihood. Test confirmatory factor analysis' results indicated that $(\chi 2=1442,660, \mathrm{p}<.01, \mathrm{CMIN} / \mathrm{df}=3.044 \mathrm{GFI}=0.746 \mathrm{NFI}$ $=0.793 \mathrm{CFI}=0.850$, RMSEA $=0.96$ ), there is unacceptable fit between measurement model and data. Upon analyzing item factor loads, standard error covariance coefficients and modification indicators problematic items were identified. In the measurement model, variables ER1, ER2 and ER4 in environmental risk (ER) factor, PT1 and PT3 variables in perceived trust (PT) factor; PU1, PU5 in perceived usefulness (PU) factor; PEU2, PEU3 and PEU4 in perceived ease of use (PEU) factor; ATT4 in ATT (ATT) factor; INT2 in intension (INT) factor were excluded due to their low factor loads or excluded since their low and insignificant ( $>0.05$ ) factor loads were highly correlated with the error terms of the problems in remaining variables. Upon excluding these statements, the measurement model was finalized in format and confirmatory analysis was repeated.

The fit indices $(\mathrm{CMIN} / \mathrm{df}=1.866$, GFI $=0.888$, $\mathrm{NFI}=0.917, \mathrm{CFI}=0.959, \mathrm{RMSEA}=0.062)$ indicated that, there was acceptable fit between the data and the model. Goodness of fit values for item factor loads and measurement model are shown on Table 1 and Table 2.

Table 1: Measurement items \& reliability

\begin{tabular}{lccc}
\hline Construct & $\begin{array}{c}\text { Average } \\
\text { Variance } \\
\text { Extracted } \\
\text { (AVE) }\end{array}$ & $\begin{array}{c}\text { Cronbach } \\
\text { Alpha }\end{array}$ & $\begin{array}{c}\text { Composite } \\
\text { Reliability } \\
\text { (CR) }\end{array}$ \\
\hline $\begin{array}{l}\text { Perceived } \\
\text { Reputation }\end{array}$ & 0,53 & 0,779 & 0,77 \\
$\begin{array}{l}\text { Enviromental } \\
\text { Risk }\end{array}$ & 0,56 & 0,719 & 0,71 \\
$\begin{array}{l}\text { Perceived Trust } \\
\text { Perceived }\end{array}$ & 0,80 & 0,924 & 0,92 \\
Usefulness & 0,69 & 0,899 & 0,87 \\
$\begin{array}{l}\text { Perceived Ease } \\
\text { of Use }\end{array}$ & 0,79 & 0,887 & 0,88 \\
$\begin{array}{l}\text { Perceived } \\
\text { Mobility }\end{array}$ & 0,70 & 0,897 & 0,87 \\
\hline $\begin{array}{l}\text { Attitude } \\
\text { Intention }\end{array}$ & 0,81 & 0,931 & 0,93 \\
\hline
\end{tabular}

It was revealed that composite reliability (C.R.) values were above 0.70 (Hair et al., 1995; Yap and Khong, 2006), which is threshold value for all variables. It was then identified that Cronbach alpha coefficients were also greater than the threshold value of 0.70 , thus it was concluded that the scales were reliable (Berthon, Ewing and Hah, 2005; Kim, Soon, et al., 2007).

Table 2: Item-factor loads

\begin{tabular}{|c|c|}
\hline & $\begin{array}{l}\text { Factor } \\
\text { Loads }\end{array}$ \\
\hline \multicolumn{2}{|l|}{ Perceived Reputation } \\
\hline $\begin{array}{l}\text { PR1: I believe this mobile service provider has a } \\
\text { good reputation.. }\end{array}$ & $0,70^{* *}$ \\
\hline $\begin{array}{l}\text { PR2: I believe this mobile service provider has a } \\
\text { reputation for being fair. }\end{array}$ & $0,78^{* *}$ \\
\hline $\begin{array}{l}\text { PR3: I believe this mobile service provider has a } \\
\text { reputation for being honest. }\end{array}$ & $0,71^{* *}$ \\
\hline \multicolumn{2}{|l|}{ Environmental Risk } \\
\hline $\begin{array}{l}\text { ER3: I believe there is a high probability of losing } \\
\text { a great deal in using mobile payment systems. }\end{array}$ & $0,78^{* *}$ \\
\hline $\begin{array}{l}\text { ER5: I believe that overall riskiness of mobile } \\
\text { payment systems is high. }\end{array}$ & $0,71^{* *}$ \\
\hline \multicolumn{2}{|l|}{ Percieved Trust } \\
\hline PTR2: I trust mobile payment systems to be secure. & $0,92^{* *}$ \\
\hline $\begin{array}{l}\text { PTR3: I believe mobile payment systems are } \\
\text { trustworthy. }\end{array}$ & $0,89^{* *}$ \\
\hline PTR4: I trust mobile payment systems. & $0,88^{* *}$ \\
\hline \multicolumn{2}{|l|}{ Perceived Usefulness } \\
\hline $\begin{array}{l}\text { PU2: Using mobile payment systems would } \\
\text { improve my performance in making payments. }\end{array}$ & $0,78^{* *}$ \\
\hline $\begin{array}{l}\text { PU3: Using mobile payment systems would } \\
\text { enhance my effectiveness in making payments. }\end{array}$ & $0,82^{* *}$ \\
\hline $\begin{array}{l}\text { PU4: Using mobile payment systems would make } \\
\text { it easier for me to manage and make payments. }\end{array}$ & $0,90^{* *}$ \\
\hline \multicolumn{2}{|l|}{ Perceived Ease of Use } \\
\hline $\begin{array}{l}\text { PEU1: Learning to use mobile payment systems } \\
\text { would be easy for me. }\end{array}$ & $0,90^{* *}$ \\
\hline $\begin{array}{l}\text { PEU5: Overall, I would find mobile payment } \\
\text { systems to be easy to use. }\end{array}$ & $0,88^{* *}$ \\
\hline \multicolumn{2}{|l|}{ Perceived Mobility } \\
\hline $\begin{array}{l}\text { PM1: I believe mobile payment is independent of } \\
\text { time. }\end{array}$ & $0,88^{* *}$ \\
\hline $\begin{array}{l}\text { PM2: I believe mobile payment is independent of } \\
\text { place }\end{array}$ & $0,79^{* *}$ \\
\hline $\begin{array}{l}\text { PM3: I can use mobile payment anytime while } \\
\text { travelling. }\end{array}$ & $0,84^{* *}$ \\
\hline \multicolumn{2}{|l|}{ Attitude towards the use of MPS } \\
\hline $\begin{array}{l}\text { ATT: Using mobile payment services is a good } \\
\text { idea. }\end{array}$ & $0,94^{* *}$ \\
\hline ATT2: Using mobile payment services is wise. & $0,89^{* *}$ \\
\hline $\begin{array}{l}\text { ATT3: Using mobile payment services is } \\
\text { beneficial. }\end{array}$ & $0,88^{* *}$ \\
\hline \multicolumn{2}{|l|}{ Intention to Use of MPS } \\
\hline $\begin{array}{l}\text { IU1: Given the opportunity, I will use mobile } \\
\text { payment services. }\end{array}$ & $0,80^{* *}$ \\
\hline $\begin{array}{l}\text { IU3: I will strongly recommend others to use } \\
\text { mobile payment systems. }\end{array}$ & $0,79^{* *}$ \\
\hline
\end{tabular}

As the factor loads of questions are examined, it surfaces that all questions are loaded in a high and significant factor load to the factors to which they belonged; hence convergent validity was achieved. Besides, the fact that explained variance coefficient for all scales is above 0.50 is another indicator of achieving convergent validity (Fornell \& Lacker, 1981). 


\subsection{Testing the Hypotheses}

Structural model created by latent variables to check the hypotheses of research was tested by utilizing the maximum-likelihood calculation technique. Goodness of fit indices indicated an acceptable fit $(\chi 2=317.187, \mathrm{CMIN} / \mathrm{df}=1.866$, GFI $=0.888$, NFI $=$ 0.917, CFI= 0.959, RMSEA= 0.062). Upon conducting an overall analysis on the created model, the findings on the relationships promulgated in research hypotheses are as displayed on Table 3.

\section{Table 3: Hypothesis Testing}

\begin{tabular}{|l|c|c|c|c|c|c|}
\hline Hyphoteses & Coefficient & $\begin{array}{c}\text { Std. } \\
\text { Coefficient }\end{array}$ & $\begin{array}{c}\text { Std. } \\
\text { Error }\end{array}$ & t & p & Result \\
\hline $\mathrm{H}_{1}:$ Perceived Reputation $\Rightarrow$ Perceived Trust & .484 & .452 & .82 & 5.864 & $* * *$ & Supported \\
\hline $\mathrm{H}_{2}$ :Envitomental Risk $\Rightarrow$ Perceived Trust & .513 & .464 & .093 & -5.504 & $* * *$ & Supported \\
\hline $\mathrm{H}_{3}:$ Perceived Trust $\Rightarrow$ Attitude & .117 & .110 & .048 & 2.442 & .015 & Supported \\
\hline $\mathrm{H}_{4}:$ Perceived Usefuluess $\Rightarrow$ Attitude & .127 & .110 & .164 & 0.775 & .438 & Rejected \\
\hline $\mathrm{H}_{5}:$ Perceived Ease of Use $\Rightarrow$ Attitude & -.137 & .133 & .148 & -0.921 & .357 & Rejected \\
\hline $\mathrm{H}_{6}:$ Perceived Mobility $\Rightarrow$ Attitude & .864 & .879 & .228 & 3.791 & $* * *$ & Supported \\
\hline $\mathrm{H}:$ Attitude $\Rightarrow$ Intentionto Use & .770 & .861 & .059 & 13.010 & $* * *$ & Supported \\
\hline
\end{tabular}

\section{Conclusion}

Penetration of smartphones and entrance of $3 \mathrm{G}$ 's to our lives make a big change. Mobil devices were only used for communication, but now they are observed in all areas of life. Mobil devices are developing over time to mobile wallets and consumers can make their payment through these devices. The objective of this study was to find the factors affecting the adoption of MPS and to find out how these factors affected the intention to use payment systems. The starting point of the research was to determine the factors affecting MPS technologies' rapidly emerging with present conditions. As a result of the analyses, it was revealed that Perceived Trust, Perceived Mobility and Attitude factors have a positive effect on the adoption of MPS. Moreover, this study did not detect any significant evidence for Perceived Usefulness and Perceived Ease of Use factors on the adoption of MPS. Another set of findings were the positive effect of reputation and the negative effect of environmental risk on Perceived Trust factor.

One of the most striking results from the data is that, mobility has the biggest effect on adoption of MPS compared to other factors. This study produced results that contribute to the findings of the previous work in this field (Schierz et. al, 2010). The results of this study indicate that MPS gives consumers freedom in terms of time and location, so consumers are disposed to use MPS. Businesses using online payment system should provide more mobility to reach more consumers. Using mobile payment instruments when being on the move brings important advantages to customers.

A number of factors were tested as the antecedents of trust in previous studies. In this paper, we have tested two of the antecedents of trust; reputation and environmental risk. With a fast digital conversion, the environmental risk is increasing. Users of MPS face with lose of information in some cases and these probable risk factors lead the users change their point of view about MPS. Furthermore, firm reputation is directly associated with Adoption of MPS. A negative relationship was found between environmental risk and perceived trust, and also a positive relationship was found between firm reputation and perceived trust. This means that, if environmental risk increases, it would cause a decrease in user trust and if firm reputation increases, it could increase trust. This study confirms that environmental risk and firm reputation are associated with trust (Chandra et. al, 2010).

The results of this study did not show any significant effect between the perceived ease of use and Adoption of MPS. Tech-savvy individuals could use mobile payment applications, but others may experience difficulty. Within this scope, the relationship between perceived ease of use and adoption of MPS may be insignificant. There are different findings on the literature about perceived ease of use. Some of the researchers have detected significant effect for perceived ease of use on Adoption of MPS (Schierz et al., 2010; Kim et al., 2010) and some others haven't found any effect (Chandra et al., 2010). The current study found that perceived usefulness has no effect on Adoption of MPS. However, the finding of the current study does not support the previous researches (Chandra et al., 2010; Schierz et al., 2010; Kim et al., 2010). Perceived usefulness has no effect on MPS likewise. As a result, users' perceived trust on MPS and mobility perception creates positive attitude toward MPS and this situation turn into intention to use MPS. The present findings seem to be consistent with other research, which found that attitudes towards the use have a positive effect on intention to use MPS (Amoako-Gyampah and Salam, 2004; Chau and Hu, 2002; Huang, 2005).

\section{Limitations of the Research and Recommendations for the Future Studies}

The generalizability of these results is subject to certain limitations. For instance, in the literature, there are plenty of antecedents of Adoption of MPS, but in this study only perceived trust, perceived usefulness, perceived ease of use and perceived mobility were analyzed. Other factors affecting Adoption of MPS can be added to future research models. In addition, the effects of several mediator variables could also be analyzed within the scope of those models.

The second limitation of this research is that since it would be a challenge to reach the entire population, the convenience sampling method was selected. A sample cannot possibly represent the entire population completely. Consequently, it is not feasible to 
generalize the results obtained from this research. Another limitation is that, due to limited budget the research was failed to encompass a wider territory.

Following this study, some suggestions may be offered for future studies. The research was conducted solely in Turkey. In future studies, it is possible to conduct comparative studies in which other factors are included in the research. Moreover, the research model might be tested by conducting intercultural research among individuals in various countries.

\section{REFERENCES}

Adams, D. A., Nelson, R. R., \& Todd, P. A. (1992). Perceived usefulness, ease of use, and usage of information technology: a replication. MIS quarterly, 227-247.

Amoako-Gyampah, K., \& Salam, A. F. (2004). An extension of the technology acceptance model in an ERP implementation

environment. Information

Management, 41(6), 731-745.

Barnes, S.,J. (2002). Wireless digital advertising: Nature and implications. International Journal of Advertising, 21, 399-420.

Berthon, P., Ewing, M., \& Hah, L. L. (2005). Captivating company: Dimensions of attractiveness in employer branding. International journal of advertising, 24(2), 151-172.

Blöchlinger, M. (2012). Mobile Payment Systems. Internet Economics VI, 41.

Bozkurt, M. (2011). İşletmelerin İtibar Yönetimi Faaliyetlerinin Müşteri Tutum ve Tercihleri Üzerindeki Yansımaları. Uşak Üniversitesi Sosyal Bilimler Dergisi,2011(7).

Chau, P. Y., \& Hu, P. J. H. (2002). Investigating healthcare professionals' decisions to accept telemedicine technology: an empirical test of competing theories. Information \& management, 39(4), 297-311.

Childers, T. L., Carr, C. L., Peck, J., \& Carson, S. (2002). Hedonic and utilitarian motivations for online retail shopping behavior. Journal of retailing,77(4), 511-535.

Davis, F. D. (1989). Perceived usefulness, perceived ease of use, and user acceptance of information technology. MIS quarterly, 319-340.

Demircan, N., \& Ceylan, A. (2003). Örgütsel güven kavramı: Nedenleri ve sonuçları. Yönetim ve Ekonomi: Celal Bayar Üniversitesi İktisadi ve İdari Bilimler Fakültesi Dergisi, 10(2), 139150.

Devaraj, S., Fan, M., \& Kohli, R. (2002). Antecedents of B2C channel satisfaction and preference: validating e-commerce metrics. Information systems research, 13(3), 316-333.

Fornell, C., \& Larcker, D. F. (1981). Evaluating structural equation models with unobservable variables and measurement error. Journal of marketing research, 39-50. http://dx.doi.org/10.2307/3151312

Gefen, D., \& Straub, D. W. (2000). The relative importance of perceived ease of use in IS adoption: a study of ecommerce adoption. Journal of the Association for Information Systems, 1(1), 8.

Gefen, D., Karahanna, E., \& Straub, D. W. (2003). Trust and TAM in online shopping: an integrated model. MIS quarterly, 27(1), 51-90.

Hair J.F., Anderson R.E., Tahtam R.L. and Balck V.C.. (1995), Multivarite Data Analysis with Reading” Prentice Hall, International Inc, A Viacorn Company, New Jersey.

Huang, E. (2005). The acceptance of womencentric websites. The Journal of Computer Information Systems, 45(4), 75.

IAB (2010), \$6.4 Billion in Q3 2010 Sets New Record for Internet Advertising Revenues, retrieved from http://www.iab.net/about_the_iab/recen t_press_releases/press_release_archive/ 
press_release/pr-111710 (Access Date: 03.03.2014)

Ipsos

ING

http://www.ing.com/web/file?uuid=fde 0bb20-c23c-4a70-9b58-

7ed3d6ec95e2\&owner=b03bc017-

e0db-4b5d-abbf-

003b12934429\&contentid=33730

(Access date: 10.11.2015)

Jin, B., Yong Park, J., \& Kim, J. (2008). Crosscultural examination of the relationships among firm reputation, esatisfaction, e-trust, and eloyalty.International Marketing Review, 25(3), 324-337.

Kalkan, A. (2011). Kişisel Tutum, Öznel Norm Ve Algılanan Davranış Kontrolünün Girişimcilik Niyeti Üzerindeki Etkisi: Üniversite Öğrencileri Üzerine Bir Uygulama. Journal Of Süleyman Demirel University Institute Of Social Sciences Year, 2(14).

Kannan, P. K., Chang, A. M., \& Whinston, A. B. (2001). Wireless commerce: marketing issues and possibilities. In System Sciences. Proceedings of the 34th Annual Hawaii International Conference on System Sciences. IEEE.

Karatepe, S. (2008). İtibar yönetimi: Halkla ilişkilerde güven yaratma.Elektronik Sosyal Bilimler Dergisi, 23(23).

Karnouskos, S. (2004). Mobile payment: a journey through existing procedures and standardization initiatives. Communications Surveys \& Tutorials, IEEE,6(4), 44-66.

Karnouskos, S., Hondroudaki, A., Vilmos, A., \& Csik, B. (2004). Security, trust and privacy in the secure mobile payment service. In 3rd International Conference on Mobile Business (pp. 3$5)$.

Kim, B. G., Park, S. C., \& Lee, K. J. (2008). A structural equation modeling of the Internet acceptance in Korea. Electronic Commerce Research and Applications, 6(4), 425-432.

Kim, C., Mirusmonov, M., \& Lee, I. (2010). An empirical examination of factors influencing the intention to use mobile payment. Computers in Human Behavior, 26(3), 310-322.

Kim, C., Tao, W., Shin, N., \& Kim, K. S. (2010). An empirical study of customers' perceptions of security and trust in e-payment systems. Electronic Commerce Research and Applications, 9(1), 84-95.

Küçük, E. (2012). Planlanmış Davranış Teorisi Çerçevesinde Mali Müşavir (SMMM) Olma Niyetinin Altında Yatan Faktörlerin Analizi. Uluslararası Yönetim İktisat ve İşletme Dergisi, 7(14), 145-162.

Lu, J., Yu, C. S., Liu, C., \& Yao, J. E. (2003). Technology acceptance model for wireless Internet. Internet Research, 13(3), 206-222.

Mallat, N. (2007). Exploring consumer adoption of mobile payments-A qualitative study. The Journal of Strategic Information Systems, 16(4), 413-432.

Mallat, N. (2007). Exploring consumer adoption of mobile payments-A qualitative study. The Journal of Strategic Information Systems, 16(4), 413-432..

Mui, L., Mohtashemi, M., \& Halberstadt, A. (2002, January). A computational model of trust and reputation. In System Sciences, 2002. HICSS. Proceedings of the 35th Annual Hawaii International Conference on (pp. 24312439). IEEE.

Nakamoto, S. (2008). Bitcoin: A peer-to-peer electronic cash system.Consulted, 1(2012), 28.

Özer, G., Özcan, M., \& Aktaş, S. (2010). Muhasebecilerin bilgi teknolojisi kullaniminin teknoloji kabul modeli (TKM) ile incelenmesi. Journal of Yasar University, 3278, 3293.

Pavlou, P. A. (2003). Consumer acceptance of electronic commerce: Integrating trust and risk with the technology acceptance model. International journal of electronic commerce, 7(3), 101-134.

Ron, D., \& Shamir, A. (2013). Quantitative analysis of the full bitcoin transaction 
graph. In Financial Cryptography and Data Security (pp. 6-24). Springer Berlin Heidelberg.

Schierz, P. G., Schilke, O., \& Wirtz, B. W. (2010). Understanding consumer acceptance of mobile payment services: An empirical analysis. Electronic Commerce Research and Applications, 9(3), 209-216.

Srivastava, S. C., Chandra, S., \& Theng, Y. L. (2010). Evaluating the role of trust in consumer adoption of mobile payment systems: An empirical analysis.Communications of the Association for Information Systems, 27, 561-588.

Szymanski, D. M., \& Hise, R. T. (2000). Esatisfaction: an initial examination.Journal of retailing, 76(3), 309-322.

Tzou, R. C., \& Lu, H. P. (2009). Exploring the emotional, aesthetic, and ergonomic facets of innovative product on fashion technology acceptance model. Behaviour \& Information Technology, 28(4), 311-322.

Ustasüleyman, T., \& Eyüboğlu, K. (2010). Bireylerin İnternet Bankacılığını Benimsemesini Etkileyen Faktörlerin Yapısal Eşitlik Modeli ile Belirlenmesi.BDDK Bankacilık ve Finansal Piyasalar, 4(2), 11-38.

Van der Heijden, H. (2002). Factors affecting the successful introduction of mobile payment systems. BLED 2002 Proceedings, 20.

Venkatesh, V. (2000). Determinants of perceived ease of use: Integrating control, intrinsic motivation, and emotion into the technology acceptance model. Information systems research, 11(4), 342-365.

Yang, H. D., \& Yoo, Y. (2004). It's all about attitude: revisiting the technology acceptance model. Decision Support Systems, 38(1), 19-31.

Yang, S., Lu, Y., Gupta, S., Cao, Y., \& Zhang, R. (2012). Mobile payment services adoption across time: An empirical study of the effects of behavioral beliefs, social influences, and personal traits. Computers in Human Behavior,28(1), 129-142.

Yap, B. W., \& Khong, K. W. (2006). Examining the effects of customer service management (CSM) on perceived business performance via structural equation modelling. Applied Stochastic Models in Business and Industry, 22(5-6), 587-605.

Yılmaz, V., Çatalbaş, G. K., \& Çelik, H. E. (2009). Kredi Kartı Kullanma Niyetini Etkileyen Faktörlerin Yapısal Eşitlik Modeliyle Araştırılması.Bankacılar Dergisi, 68, 20-29.

Zhou, T. (2013). An empirical examination of continuance intention of mobile payment services. Decision Support Systems, 54(2), 1085-1091.

Zmijewska, A., Lawrence, E., \& Steele, R. (2004, October). Towards Understanding of Factors Influencing User Acceptance of Mobile Payment Systems. In ICWI (pp. 270-277). 